\title{
Brazilian propolis protects Saccharomyces cerevisiae cells against oxidative stress
}

\author{
Rafael A. de Sá ${ }^{1}$, Frederico A.V. de Castro ${ }^{1}$, Elis C.A. Eleutherio ${ }^{1}$, \\ Raquel M. de Souza ${ }^{2}$, Joaquim F.M. da Silva ${ }^{2}$, Marcos D. Pereira ${ }^{1}$ \\ ${ }^{1}$ Departamento de Bioquímica, Instituto de Química, Universidade Federal do Rio de Janeiro, \\ Rio de Janeiro, RJ, Brazil. \\ ${ }^{2}$ Departamento de Química Orgânica, Instituto de Química, Universidade Federal do Rio de Janeiro, \\ Rio de Janeiro, RJ, Brazil.
}

Submitted: March 05, 2012; Approved: September 10, 2012.

\begin{abstract}
Propolis is a natural product widely used for humans. Due to its complex composition, a number of applications (antimicrobial, antiinflammatory, anesthetic, cytostatic and antioxidant) have been attributed to this substance. Using Saccharomyces cerevisiae as a eukaryotic model we investigated the mechanisms underlying the antioxidant effect of propolis from Guarapari against oxidative stress. Submitting a wild type (BY4741) and antioxidant deficient strains $(\operatorname{ctt} 1 \Delta, \operatorname{sod} 1 \Delta, g \operatorname{sh} 1 \Delta, \operatorname{gtt} 1 \Delta$ and gtt $2 \Delta$ ) either to $15 \mathrm{mM}$ menadione or to $2 \mathrm{mM}$ hydrogen peroxide during $60 \mathrm{~min}$, we observed that all strains, except the mutant $\operatorname{sod} 1 \Delta$, acquired tolerance when previously treated with $25 \mu \mathrm{g} / \mathrm{mL}$ of alcoholic propolis extract. Such a treatment reduced the levels of ROS generation and of lipid peroxidation, after oxidative stress. The increase in $\mathrm{Cu} / \mathrm{Zn}$-Sod activity by propolis suggests that the protection might be acting synergistically with $\mathrm{Cu} / \mathrm{Zn}-\mathrm{Sod}$.
\end{abstract}

Key words: propolis, antioxidant, oxidative stress, Saccharomyces cerevisiae.

\section{Introduction}

Aerobic organisms have to deal with the toxic effects of reactive oxygen species (ROS). These reactive species can be formed during stress conditions such as heat shock, dehydration, toxic chemicals, UV and ionizing radiation (Lushchak, 2011). Furthermore, aerobic life style is a potential source of ROS since oxygen can be partially reduced during respiration (Lushchak, 2011; Morano et al., 2011). Indeed, when the generation of ROS overwhelms the cellular antioxidant components a drastic oxidative stress is generated. Oxidative stress promotes several damages to cell structures such as proteins, lipids and nucleic acids. Hence, modifications in such molecules have been strongly related to a number of diseases such as cancer, Alzheimer, Amyotrophic Lateral Sclerosis (ALS) and also to the process of aging (Hwang and Kim, 2007; Valko et al., 2007; Liedhegner et al., 2012) .

Cellular defense mechanisms against ROS-induced oxidative stress involve enzymatic and/or non-enzymatic factors. Enzymatic defense encompasses enzymes such as superoxide dismutases, glutathione transferases, catalase and others involved in removal, repair or detoxification of damaged intracellular components (Scandalios, 2005). On the other hand, non-enzymatic antioxidants such as ascorbic acid (Vitamin C), $\alpha$-tocopherol (Vitamin E), glutathione (GSH), carotenoids, flavonoids are mainly related to the process of ROS elimination and detoxification of pernicious components damaged by ROS (Scandalios, 2005; Valko et al., 2006).

In the last years, an increasing interest in producing or discovering new antioxidant molecules from "functional foods" is emerging. This term is used for foods that can provide not only basic nutritional or energetic requirements, but also additional components with physiological benefits, such as antioxidants which are involved in protection against ROS (Viuda-Martos et al., 2008). Aiming at reducing diseases and also the process of aging, food industries are developing antioxidant substances and/or enriched foods with antioxidants. In this field, compounds origi-

Send correspondence to M.D. Pereira. Departamento de Bioquímica, Instituto de Química, Universidade Federal do Rio de Janeiro, Rio de Janeiro, RJ, Brazil. E-mail: marcosdp@iq.ufrj.br. 
nated in the beehive, as honey, propolis and royal jelly have gained prominence (Gómez-Caravaca et al., 2006; Bouayed and Bohn, 2010; Sforcina and Bankovab, 2011).

Propolis is a natural and non-toxic resin produced by honey bees (Apis mellifera). It is extensively used in folk medicine presenting several biological applications such as immunomodulatory, antitumor, antiinflammatory, antioxidant, antibacterial, antifungal, antiviral and antiparasite activities (Dobrowolski et al., 1991; Marcucci et al., 2001; Gómez-Caravaca et al., 2006; Souza et al., 2007; Bouayed and Bohn, 2010; Sforcina and Bankovab, 2011). Currently, this product has also been used by food, pharmaceutical and cosmetic industries (Viuda-Martos et al., 2008). The complexity of its chemical composition is mainly due to the site where it is produced by bees. In fact, natural factors such as type of vegetation, zone of temperature and seasonality determine its composition (Gómez-Caravaca et al., 2006; Viuda-Martos et al., 2008; Sforcina and Bankovab, 2011). Although it is possible to find differences in propolis composition, most of the samples share common characteristics in their overall chemistry (Marcucci et al., 2001; GómezCaravaca et al., 2006; Sforcina and Bankovab, 2011). Propolis chemistry describes the existence of at least 300 different compounds; it contains $50 \%$ resin which is composed mainly by polyphenols (flavonoids, phenolic acids and their esters); $30 \%$ wax, $10 \%$ essential oils, $5 \%$ pollen and 5\% other organic compounds (Marcucci et al., 2001). Due to its composition, propolis could act as a promissory antioxidant substance reacting and scavenging ROS, however, the exact protective mechanism displayed by propolis is unknown.

In order to establish new insights regarding the antioxidant properties of propolis, we investigated the protective role of propolis during exposure of the yeast Saccharomyces cerevisiae to oxidative stress generated by $\mathrm{H}_{2} \mathrm{O}_{2}$ and menadione. Due to biochemical and molecular similarities with human cells, the yeast $S$. cerevisiae has been shown to be a powerful eukaryotic model for understanding the cellular response against stress damages (Mager and Winderickx, 2005; Khurana and Lindquist, 2010). In this work, we also report the first evidence for propolis activation of the antioxidant enzyme $\mathrm{Cu} / \mathrm{Zn}$-superoxide dismutase.

\section{Material and Methods}

\section{Chemicals}

All chemicals were purchased from Sigma (St. Louis, MO, USA). Culture media components were purchased from Becton, Dickinson and Company (Franklin Lakes, NJ, USA).

\section{Preparation of propolis extract}

Crude propolis from Guarapari was a kind gift by Prof. Monica Freimman de Souza Ramos (Faculty of Phar- macy, Federal University of Rio de Janeiro, Brazil). Guarapari is located in the coastal zone of the Brazilian state of Espirito Santo, with a tropical $A w$ climate possessing reminiscences of the original Atlantic forest. Propolis extract was prepared by static maceration of $6.0 \mathrm{~g}$ of the grounded crude propolis with $30 \mathrm{~mL}$ of absolute ethanol for one week at $28{ }^{\circ} \mathrm{C}$. After filtration to remove the insoluble residues, the extract was kept in a freezer until use as described by Souza et al., 2007 (Souza et al., 2007).

\section{Yeast strains and growth conditions}

Wild type strain of Saccharomyces cerevisiae BY4741 (MATa his3 leu2 met15 ura3) and its isogenic mutants ctt1, sodl, gshl, gtt 1 and gtt2 harboring, respectively, the genes CTT1, SOD1, GSH1, GTT1 and GTT2 interrupted by the gene KanMX4 (Euroscarf, Frankfurt, Germany) were used in this work. Stocks of yeast strains were maintained on solid $2 \%$ YPD (1\% yeast extract, $2 \%$ glucose, $2 \%$ peptone, and $2 \%$ agar). In the case of mutant strains the medium also contained $0.02 \%$ of geneticine. For all experiments, cells were grown in liquid 2\% YPD medium using an orbital shaker at $28{ }^{\circ} \mathrm{C}$ and $160 \mathrm{rpm}$ with the ratio of flask volume/medium of $5 / 1$.

\section{Oxidative stress conditions}

Cells $(50 \mathrm{mg}$ ) at the first exponential phase growing on $2 \%$ YPD were directly stressed $(15 \mathrm{mM}$ menadione or $2 \mathrm{mM} \mathrm{H}_{2} \mathrm{O}_{2}$ during $1 \mathrm{~h}$ at $28{ }^{\circ} \mathrm{C} / 160 \mathrm{rpm}$ ), or previously treated with propolis $(25 \mu \mathrm{g} / \mathrm{mL})$ during $1 \mathrm{~h}$ at $28^{\circ} \mathrm{C} / 160 \mathrm{rpm}$ (Castro, et al., 2007; Fernandes et al., 2007; Dani et al., 2008). Immediately after adaptive treatment, cells were harvested by centrifugation $(5,000 \mathrm{rpm} /$ $5 \mathrm{~min} / 4^{\circ} \mathrm{C}$ ), washed with distilled water to remove the excess of propolis in the medium and then resuspended in the original growth medium to oxidative stress.

\section{Tolerance determination}

Cell viability was analyzed by plating cells $(400 \mu \mathrm{g})$, after appropriate dilution $(1000 \mathrm{x})$, in triplicate on solidified $2 \%$ YPD medium (1\% yeast extract, $2 \%$ glucose, $2 \%$ peptone, and 2\% agar) (Castro, et al., 2007; Dani et al., 2008). The plates were incubated at $28{ }^{\circ} \mathrm{C} / 72 \mathrm{~h}$ and then colonies counted. Survival, expressed as percentage, was determined before and after oxidative stress condition, using cells treated or not with propolis $(25 \mu \mathrm{g} / \mathrm{mL})$.

\section{Lipid peroxidation assay}

Lipid peroxidation was assayed in cells exposed directly or propolis pre-treated to oxidative stress. Cells $(50 \mathrm{mg})$ cooled on ice were harvested by centrifugation $\left(5,000 \mathrm{rpm} / 5 \mathrm{~min} / 4^{\circ} \mathrm{C}\right)$, washed twice with distilled water and resuspended with $0.5 \mathrm{~mL}$ of $10 \%$ trichloracetic acid (TCA) in a test tube containing $1.5 \mathrm{~g}$ of glass beads. Cells were disrupted by 6 cycles of $20 \mathrm{~s}$ agitation on a vortex mixer followed by $20 \mathrm{~s}$ on ice. The extracts were used to de- 
tect malondialdehyde (MDA), a final product of lipid oxidation, according to Steels et al. (1994) (Steels et al., 1994).

\section{Detection of superoxide dismutase activity}

Total protein extract was prepared from exponential cells $(50 \mathrm{mg})$ treated or not with $25 \mu \mathrm{g} / \mathrm{mL}$ propolis according to Mannarino et al. (2011) (Mannarino et al., 2011). Protein concentrations were determined by the method of Stickland (1951) (Stickland, 1951). Cu/Zn-superoxide dismutase activity was analyzed loading $30 \mu \mathrm{g}$ of proteins in native $12 \%$ polyacrylamide gel electrophoresis. Electrophoresis was carried out using a Mini-Protean from Bio$\operatorname{Rad}\left(\right.$ Bio-Rad laboratories Inc, USA) at $25^{\circ} \mathrm{C}, 100 \mathrm{mV}$ during $2 \mathrm{~h}$. After electrophoresis, the gel was immersed in a solution containing $2.5 \mathrm{mM}$ nitrobluetetrazolium (NBT) and $86 \mu \mathrm{M}$ riboflavin. The reaction (10 min.) of visible light with riboflavin was sufficient to generate superoxide radicals reducing totally NBT. The activity of $\mathrm{Cu} / \mathrm{Zn}-\mathrm{Sod}$ is responsible to inhibit NBT reduction. Image analysis was performed after capture using UVP BioImaging Systems. The increase of $\mathrm{Cu} / \mathrm{Zn}$-Sod activity was determined, as percentage (\%), by the ratio of total bands area of propolis $(25 \mu \mathrm{g} / \mathrm{mL} 1 \mathrm{~h})$ treated and non treated cells.

\section{Determination of intracellular oxidation}

The levels of intracellular oxidation were measured using the oxidant sensitive probe, 2', 7'-dichlorofluorescein diacetate. Fluorescence was measured using a Cary Eclipse spectrofluorimeter at an excitation wavelength of $504 \mathrm{~nm}$ and an emission wavelength of $524 \mathrm{~nm}$. As a control, fluorescence was recorded over $1 \mathrm{~h}$ at $40{ }^{\circ} \mathrm{C}$ without any cells and with cells previously killed (data not shown). A fresh $5 \mathrm{mM}$ stock solution of probe dissolved in ethanol was added to the cell culture (to a final concentration of $10 \mu \mathrm{M}$ ) and incubated at $28^{\circ} \mathrm{C}$ to allow uptake of the probe. After $15 \mathrm{~min}$, half of the culture was directly exposed to menadione $(15 \mathrm{mM})$ while the other part was treated with propolis $(25 \mu \mathrm{g} / \mathrm{mL} 1 \mathrm{~h})$ and, thereafter, stressed with menadione. Cell extracts were prepared as previously described by Pereira et al. (2001) (Pereira et al., 2001). The results were expressed as a ratio between fluorescence of $\mathrm{H}_{2} \mathrm{DCF}$ in stressed and non-stressed cells during oxidative stress.

\section{Data analysis}

The results represent the mean \pm standard deviation of at least three independent experiments. Statistical differences were tested using t-Test. The latter denotes homogeneity between experimental groups at $\mathrm{p}<0.05$. Different letters mean statistically different results. For lipid peroxidation assay we compared the homogeneity between stressed and non stressed cells of each strain at $\mathrm{p}<0.05$.

\section{Results and Discussion}

\section{Propolis protects $S$. cerevisiae cells against superoxide stress}

Propolis is recognized as an important pharmacologic substance. Among propolis properties, its antimicrobial action is the most studied and important (Boukraâ and Sulaiman, 2009; Sforcina and Bankovab, 2011). Firstly, we investigated if propolis treatment would kill S. cerevisiae cells. Thus, we directly exposed the wild type cells to propolis. Tolerance against propolis was measured after $1 \mathrm{~h}$ exposition. According to our results, treatment with propolis in the range of $25-100 \mu \mathrm{g} / \mathrm{mL}$ was not toxic for the wild type strain BY4741. Cells continued to reach $100 \%$ tolerance (Figure 1). Since cells were not affected by low doses of propolis we decided to study its protective role against oxidative stress. The antioxidant property of propolis was analyzed exposing $S$. cerevisiae cells, treated or not with propolis $(25 \mu \mathrm{g} / \mathrm{mL})$, to menadione $(20 \mathrm{mM})$ or $\mathrm{H}_{2} \mathrm{O}_{2}(2 \mathrm{mM})$. Although menadione and $\mathrm{H}_{2} \mathrm{O}_{2}$ share similarities concerning genetic reprogramming, their mechanism of action and the stress factors involved in primary defense against these agents are quite distinct (Fernandes $e t$ al., 2007).

Menadione is a naphtoquinone used as an oxidative stress generator displaying strong ability to produce $\mathrm{O}_{2}{ }^{-}$ once inside the cells (Mauzeroll and Bard, 2004). In addition, as a mechanism of menadione elimination, a complex with glutathione (GSH) can also be formed through Gtt2 activity (Mauzeroll and Bard, 2004; Castro et al., 2007). Here, as we can see in Figure 2, cells deficient in the glutathione transferase Gtt1 (gttl $1 \Delta$ ) showed the same tolerance profile presented by the wild type. On the other hand, the Gtt2 deficient strain $(g t t 2 \Delta)$ was drastically affected by menadione stress. In spite of being hypersensitive to a di-

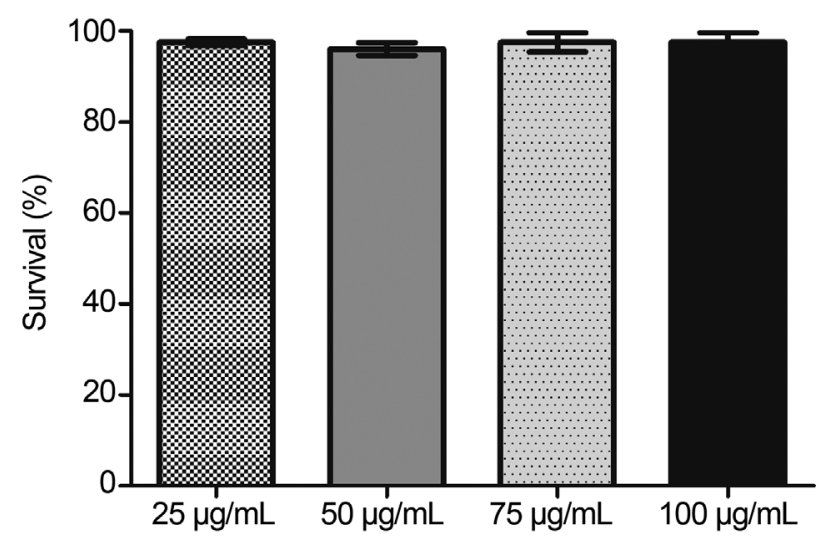

Figure 1 - Survival of $S$. cerevisiae cells exposed to increasing propolis concentrations. Exponential cells of the wild type BY4741 were directly exposed to propolis. After $1 \mathrm{~h}$, cells were plated in triplicate on solidified $2 \%$ YPD medium. The plates were incubated at $28^{\circ} \mathrm{C} / 72 \mathrm{~h}$ and then colonies counted. The results expressing percentage of survival in relation to non-stressed cells were obtained from the average \pm standard deviation of three independent experiments. 
rect exposure to menadione stress, this strain acquired tolerance after propolis treatment. In this scenario we are led to suggest that propolis administration is sufficient to overcome Gtt2 deficiency (Figure 2). GSH, $\gamma$-L-glutamyl-Lcysteinyl-glycine, is the main and multifunctional antioxidant encountered in all living cells (Hayes et al., 2005; Forman et al., 2009; Pallardó et al., 2009). In order to test whether the antioxidant potential of propolis could replace GSH, we decided to use a mutant of $S$. cerevisiae deficient in GSH synthesis $(g s h 1 \Delta)$. This strain presents a disruption in GSH1, which encodes the enzyme gamma glutamylcysteine synthetase involved in the first step of GSH synthesis. Despite the fact that cells were very sensitive to menadione stress, propolis treatment strongly increased survival of the gsh1 mutant (Figure 2). However, protection exhibited by $25 \mu \mathrm{g} / \mathrm{mL}$ propolis was not sufficient for cells to reach $100 \%$ survival (Figure 2). Indeed, full protection against menadione in strain $g \operatorname{sh} 1 \Delta$, was achieved after $50 \mu \mathrm{g} / \mathrm{mL}$ propolis treatment (data not shown). These results demonstrate that besides being very important for cellular protection against menadione stress, the deficiency in GSH is bypassed by propolis treatment, presumably due to components with antioxidant properties in the propolis extract.

Superoxide dismutases (Sods) are very important metallo-enzymes involved in cellular protection against superoxide $\left(\mathrm{O}_{2}{ }^{-{ }^{-}}\right)$toxicity. Among Sods, $\mathrm{Cu} / \mathrm{Zn}-\mathrm{Sod}$ is designed as the first line of defense against $\mathrm{O}_{2}{ }^{-}$toxicity and it is found in many of eukaryotic organelles (Bonatto, 2007; Abreu and Cabelli, 2010). Regarding to Mn-Sod function, located in mitochondria, it appears to be restricted to protect cells against $\mathrm{O}_{2}{ }^{-}$radicals produced as by-products of

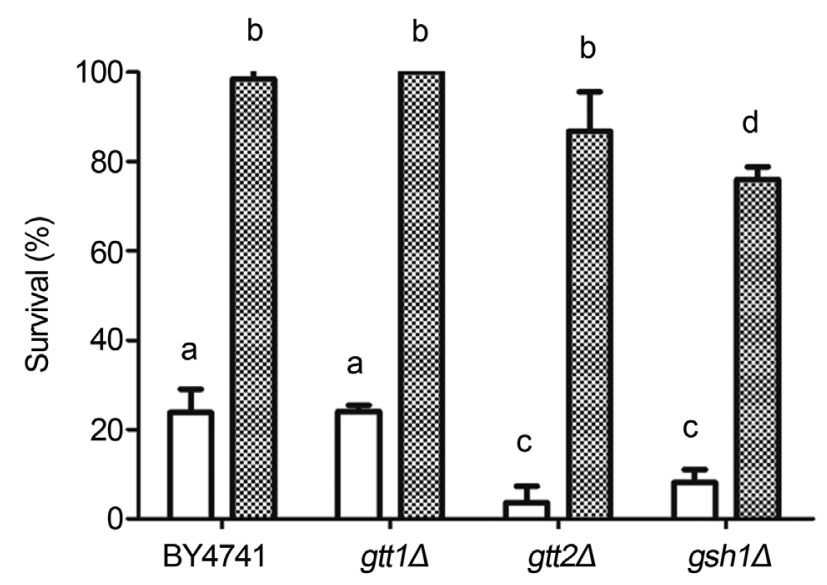

Figure 2 - Effect of propolis treatment on cellular survival against menadione. Wild type (BY4741) and mutants strains gtt $1 \Delta$, gtt2 $\Delta$ and $g \operatorname{sh} 1 \Delta$, harvested in mid exponential phase, were stressed with $15 \mathrm{mM}$ menadione/ 1 h. Cells were directly stressed (white bars) or previously treated with $25 \mu \mathrm{g} / \mathrm{mL}$ propolis during $1 \mathrm{~h}$ before being exposed to menadione stress (hatched bars). The results expressing percentage of survival in relation to non-stressed cells were obtained from the average \pm standard deviation of three independent experiments. Different letters mean statistically different results. respiration and/or other processes inside of mitochondria (Fridovich, 1995). Furthermore as already described yeast strains are highly damaged when SOD1 mutations are present (Wallace et al., 2005). Thus, in this work using a mutant strain of $S$. cerevisiae defective in $\mathrm{Cu} / \mathrm{Zn}-\mathrm{Sod}(\operatorname{sod} 1 \Delta)$ biosynthesis, we investigated whether propolis would still be able to protect $\operatorname{sod} 1 \Delta$ cells after menadione stress. Menadione is a redox cycling agent reacting with cytoplasmic components generating $\mathrm{O}_{2}{ }^{--}$radicals. Therefore the $\mathrm{Cu} / \mathrm{Zn}$-Sod must be essential in yeast response against this stress. As expected, the sod $1 \Delta$ mutant strain was hypersensitive after menadione stress (Figure 3). Propolis treatment conferred small protection to the sod $1 \Delta$ mutant, not sufficient to recover the hypersensitive phenotype of cells (Figure 3). Different from the data obtained with the gsh1 $1 \Delta$ mutant, the increase of propolis concentration $(50 \mu \mathrm{g} / \mathrm{mL})$ did not improve sod $1 \Delta$ tolerance (Figure 3). Taken together, our results with $\operatorname{sod} 1 \Delta$, suggest that propolis might be acting in synergy with $\mathrm{Cu} / \mathrm{Zn}$-Sod or, perhaps, activating this enzyme.

To test our hypothesis, the activity of $\mathrm{Cu} / \mathrm{Zn}$-Sod was assessed, as well as, whether propolis had the potential to activate the metal catalyzed reaction of $\mathrm{Cu} / \mathrm{Zn}$-Sod. After propolis treatment, a $63 \%( \pm 4.2)$ increase in $\mathrm{Cu} / \mathrm{Zn}$-Sod activity was observed in the wild type strain. That non-lethal menadione stress induces $\mathrm{Cu} / \mathrm{Zn}$-Sod activity has been previously described (Mannarino et al., 2011). We used the well defined menadione treatment $(0.5 \mathrm{mM} / 60 \mathrm{~min})$ as a reference for the increase in $\mathrm{Cu} / \mathrm{Zn}$-Sod activity. The activation of $\mathrm{Cu} / \mathrm{Zn}-\mathrm{Sod}$, promoted by propolis, was higher than menadione, $63 \%( \pm 4.2)$ vs $50 \%( \pm 6.4)$. We can, therefore, conclude that $\operatorname{sod} 1 \Delta$ did not acquire tolerance, as observed by the other strains, due to the impossibility of

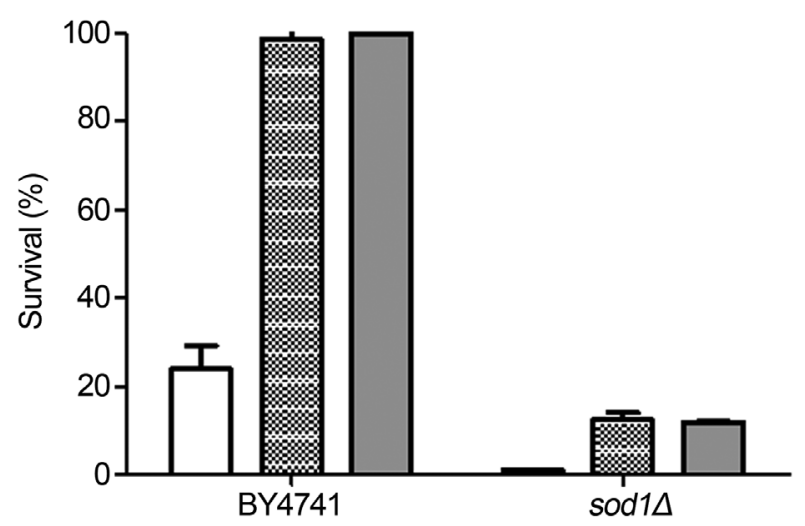

Figure 3 - Dependence of $\mathrm{Cu} / \mathrm{Zn}$-Sod for full protection after propolis treatment. Wild type and mutant strains, harvested in mid exponential phase, were stressed with $15 \mathrm{mM}$ menadione $/ 60 \mathrm{~min}$. Cells were directly stressed (white bars) or previously treated with $25 \mu \mathrm{g} / \mathrm{mL}$ (hatched bars) or $50 \mu \mathrm{g} / \mathrm{mL}$ (gray bars) propolis during $1 \mathrm{~h}$ before being exposed to menadione. The results expressing percentage of survival in relation to nonstressed cells were obtained from the average \pm standard deviation of three independent experiments. Different letters mean statistically different results. 
increasing $\mathrm{Cu} / \mathrm{Zn}$-Sod activity, which in fact is absent in the sod $1 \Delta$ mutant. Contrasting with current results, Kanbur et al. (2008) (Kanbur et al., 2008) obtained in studies of the effect of propolis in drug protection, we did not detect any statistical differences in activity of the antioxidant enzymes such as superoxide dismutase, catalase and glutathione peroxidase when propolis was added to experimental groups. Here, we show the first evidence that propolis triggered the activation of $\mathrm{Cu} / \mathrm{Zn}$-Sod, one of the best characterized and most important antioxidant enzymes.

Biomarkers of oxidative stress are extremely useful in evaluating cytotoxicity. Among them, intracellular oxidation is one of the best characterized and explored biomarkers used to detect oxidative stress (Bartosz, 2006). In this work, using the fluorescent probe 2',7'-dichlorofluorescein diacetate $\left(\mathrm{H}_{2} \mathrm{DCF}-\mathrm{DA}\right)$ we determined the levels of intracellular oxidation during menadione stress. $\mathrm{H}_{2} \mathrm{DCF}$ DA is a fluorogenic probe that can permeate the cell membrane by passive diffusion and is deacetylated by cytossolic esterases. $\mathrm{H}_{2} \mathrm{DCF}$ is more polar than the parent compound thus being trapped within the cell. Once inside the cell, it becomes susceptible to the attack by ROS, yielding a high fluorescent product (Bartosz, 2006). Recently, propolis from the Slovenian region was described as being able to reduce the levels of intracellular oxidation in cells (wild type) of S. cerevisiae (Tanja et al., 2011). The levels of intracellular oxidation were measured only in cells at stationary growth phase without any oxidative treatment. $\mathrm{Cu}-$ riously, although propolis did not increase cell viability, the authors stated that propolis also influences cell energy metabolism and protein patterns. In our approach, we decided to measure the levels of intracellular oxidation in $S$. cerevisiae cells exposed to lethal oxidative stress conditions. Direct exposure to menadione produced an increase of $\mathrm{H}_{2} \mathrm{DCF}$ fluorescence in the wild type strain and also in the sodl mutant strains (Table 1). However, after propolis treatment, a reduction of $\mathrm{H}_{2} \mathrm{DCF}$ oxidation was observed in both strains, indicating a potent antioxidant property of propolis (Table 1). Unexpectedly, although it is easy to correlate the levels of intracellular oxidation with tolerance in the wild type, the reduction in intracellular oxidation in mutant $\operatorname{sod} 1 \Delta$, by the propolis treatment was not accompanied

Table 1 - Effect of propolis treatment in reducing the levels of intracellular oxidation (ROS production) after menadione stress.

\begin{tabular}{lcc}
\hline & \multicolumn{2}{c}{ Relative fluorescence } \\
\cline { 2 - 3 } Strains & Not treated & Treated \\
\hline Wild type & $1.3^{\mathrm{a}} \pm 0.1$ & $0.8^{\mathrm{b}} \pm 0.1$ \\
sod1 $1 \Delta$ & $2.2^{\mathrm{c}} \pm 0.3$ & $1.0^{\mathrm{b}} \pm 0.2$ \\
\hline
\end{tabular}

The Wild type and $\operatorname{sod} 1 \Delta$ strains were directly stressed with menadione $(15 \mathrm{mM})$ or previously propolis treated $(25 \mu \mathrm{g} / \mathrm{mL})$ during $60 \mathrm{~min}$ before being stressed with menadione. The results expressing relative fluorescence were obtained from the average \pm standard deviation of three independent experiments. Different letters mean statistically different results. by acquisition of tolerance. This result confirms our hypothesis that propolis protected yeast cells by reducing the levels of ROS. However the activation of $\mathrm{Cu} / \mathrm{Zn}$-Sod was crucial for cellular adaptation and response to stress condition. Thus, propolis action might be related to components in propolis, which are able to activate the antioxidant enzyme $\mathrm{Cu} / \mathrm{Zn}$-Sod and also, presumably, by scavenging ROS during stress.

\section{Cytotoxicity of $\mathrm{H}_{2} \mathrm{O}_{2}$ is also alleviated by propolis treatment}

Hydrogen peroxide $\left(\mathrm{H}_{2} \mathrm{O}_{2}\right)$ is the most abundant reactive oxygen species in vivo, being continuously produced as a by-product of aerobic metabolism (Kakinuma et al., 1979). Changes in gene expression by $\mathrm{H}_{2} \mathrm{O}_{2}$ and $\mathrm{O}_{2}{ }^{*-}$ involve similar targets, however, we have previously described that the cellular response to both conditions is quite distinct (Fernandes et al., 2007). In Saccharomyces cerevisiae, the response to $\mathrm{H}_{2} \mathrm{O}_{2}$ seems to be mainly related to the levels of GSH and to the activity of catalase (Ctt1) (Forman et al., 2009). In order to investigate the potential of propolis in protecting yeast cells against $\mathrm{H}_{2} \mathrm{O}_{2}$ stress we decided to perform experiments using the wild type strain and mutant strains harboring deficiency in either GSH or Ctt1 synthesis. According to Figure 4, cells were drastically affected by direct exposure to $\mathrm{H}_{2} \mathrm{O}_{2}$. However, after propolis treatment, survival increased almost 3 times. No significant differences were observed between strains, suggesting that propolis compensates deficiencies in both GSH and $\mathrm{Ctt} 1$.

Oxidative stress generated by $\mathrm{H}_{2} \mathrm{O}_{2}$ frequently induces oxidative damages in biomolecules such as lipid, proteins and DNA (Benaroudj et al., 2001; Hwang and Kim, 2007; Nery et al., 2008). However, a reduction in lipid and protein oxidation is observed in cells pre-adapted and

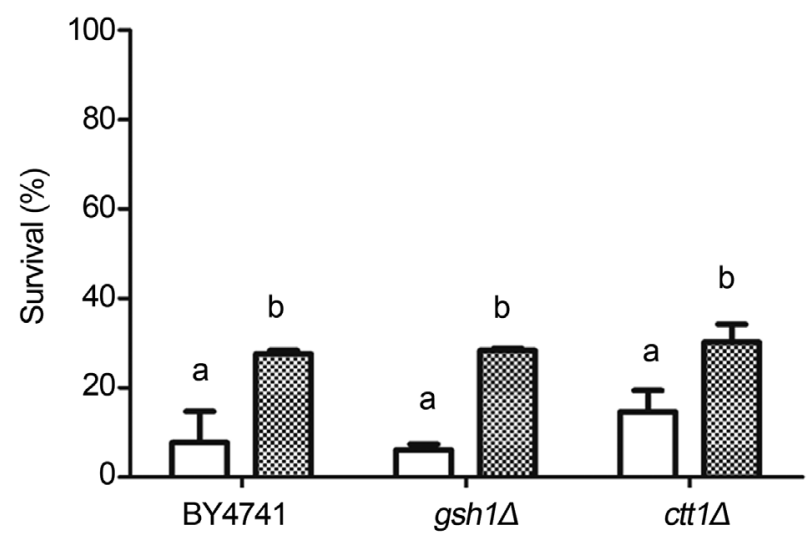

Figure 4 - Effect of propolis treatment on cellular survival after exposure to $\mathrm{H}_{2} \mathrm{O}_{2}$. Wild type and mutants strains were harvested in the mid exponential phase and stressed with $2 \mathrm{mM} \mathrm{H}_{2} \mathrm{O}_{2} / 1 \mathrm{~h}$. Cells were directly stressed (white bars) or previously treated with propolis $(25 \mu \mathrm{g} / \mathrm{mL})$ during $60 \mathrm{~min}$ before being exposed to $\mathrm{H}_{2} \mathrm{O}_{2}$ stress (hatched bars). The results expressing percentage of survival in relation to non-stressed cells were obtained from the average \pm standard deviation of three independent experiments. Different letters mean statistically different results. 
subsequently exposed to $\mathrm{H}_{2} \mathrm{O}_{2}$ (Benaroudj et al., 2001; Fernandes et al., 2007; Nery et al., 2008; Dani et al., 2008). Here, lipid peroxidation was assessed by TBARS (Thiobarbituric Acid Reactive Substances) using exponential cells exposed or not to $\mathrm{H}_{2} \mathrm{O}_{2}$. Propolis treated cells exposed to $\mathrm{H}_{2} \mathrm{O}_{2}$ were also examined. As expected, exposure of cells to $\mathrm{H}_{2} \mathrm{O}_{2}$ increased dramatically the levels of lipid peroxidation (Table 2). In fact, high levels of lipid peroxidation are frequently associated with impairment of growth and survival of yeast cells treated with $\mathrm{H}_{2} \mathrm{O}_{2}$ (Benaroudj et al., 2001; Fernandes et al., 2007; Nery et al., 2008; Dani et al., 2008). Propolis treatment reduced lipid oxidation in all $S$. cerevisiae strains (Table 2). Despite reducing lipid peroxidation, propolis did not restore basal lipid peroxidation levels, suggesting that $\mathrm{H}_{2} \mathrm{O}_{2}$ was still exerting its toxic effect on cells (Table 2). This result is in accordance with the observed tolerance of cells which was not fully restored in cells treated with propolis. Protection of carps (Cyprinus carpio) from oxidative damages generated by chromium (VI) by propolis has been recently shown (Yonar et al., 2011). After 28 days of simultaneous administration of propolis and chromium, the levels of lipid peroxidation were decreased together with the increase in activity of antioxidant enzymes such as superoxide dismutase, catalase and glutathione peroxidase. Unfortunately, the author did not determine which isoform was involved in that activity.

The Brazilian propolis used in this study is especially rich in phenolic acids contrasting with those originating from European and other temperate regions (Bankova et al., 1995; 2002). It was characterized the presence of caffeic acid, drupanin, $p$-coumaric acid, 3,4-dimethoxycinnamic acid, quercetin, pinobanksin 5-methyl ether, apigenin, kaempferol, pinobanksin, cinnamylideneacetic acid, chrysin, pinocembrin, galangin, pinobanksin 3-acetate, phenethyl caffeate, cinnamyl caffeate, tectochrysin, artepillin C (Marcucci et al., 2001, Souza et al., 2007). Recently, propolis and its components, caffeic and cinamic acid derivatives were shown to prevent oxidative damages in cell membranes and DNA (Benkovic et al., 2008; Prasad

Table 2 - Determination of lipid peroxidation in $S$. cerevisiae cells after $\mathrm{H}_{2} \mathrm{O}_{2}$ stress.

\begin{tabular}{lccc}
\hline & & \multicolumn{2}{c}{$\mathrm{H}_{2} \mathrm{O}_{2}$} \\
\cline { 3 - 4 } Strains & Non stressed & Stressed & Propolis treated \\
\hline Wild type & $59.6^{\mathrm{a}} \pm 1.6$ & $140.0^{\mathrm{b}} \pm 6.0$ & $111.7^{\mathrm{c}} \pm 1.8$ \\
gsh1 $1 \Delta$ & $62.3^{\mathrm{a}} \pm 3.2$ & $183.4^{\mathrm{d}} \pm 4.3$ & $161.4^{\mathrm{e}} \pm 2.7$ \\
ctt1 & $46.7^{\mathrm{a}} \pm 2.1$ & $120.5^{\mathrm{c}} \pm 6.5$ & $92.2^{\mathrm{f}} \pm 7.1$ \\
\hline
\end{tabular}

Lipid peroxidation was analyzed in exponential cells of the wild type and mutant strains after $2 \mathrm{mM} \mathrm{H}_{2} \mathrm{O}_{2}$. Non stressed, stressed $\left(2 \mathrm{mM} \mathrm{H}_{2} \mathrm{O}_{2}\right)$ and propolis treated cells were lysed by TCA $10 \%$ and extracts used to determine malondialdehyde (pmoles of $\mathrm{MDA} / \mathrm{mg}$ of cell dry weight) levels. Lipid peroxidation data was obtained from the average \pm standard deviation of three independent experiments. Different letters mean statistically different results. et al., 2009). Artepillin C (3,5-diprenyl-4-hydroxycinamic acid), another phenolic substance found in large concentration in Brazilian propolis inhibited lipid peroxidation in different cell models (Shimizu et al., 2004). Souza et al. (2007), described that Brazilian propolis from Guarapari is largely composed by phenolic acids such as caffeic acid, drupanin (3-prenyl-4-hydroxycinamic acid), artepillin C and cinamic acid which might be acting as an antioxidant protecting yeast cells against $\mathrm{H}_{2} \mathrm{O}_{2}$ stress.

\section{Conclusions}

Based on these results we may conclude that propolis from Guarapari (Brazil) is a promissing antioxidant product due to three main reasons: (i) it contributes to protect membrane lipids from $\mathrm{H}_{2} \mathrm{O}_{2}$ stress; (ii) in response to an $\mathrm{O}_{2}{ }^{-}$stress mediated by menadione, propolis acts maintaining the redox status by scavenging ROS and (iii) it activates $\mathrm{Cu} / \mathrm{Zn}$-superoxide dismutase, one of the most important antioxidant enzymes.

\section{Acknowledgments}

This work is supported by grants from FAPERJ, CAPES and CNPq.

\section{References}

Abreu IA, Cabelli DE (2010) Superoxide dismutases - A review of the metal-associated mechanistic variations. Biochim Biophys Acta 1804:263-274.

Bankova V, Christov R, Kujumgiev A, Marcucci MC, Popov S (1995) Chemical composition and antibacterial activity of Brazilian propolis. Z Naturforsch C 50:167-172.

Bankova V, Popova M, Bogdanov S, Sabatini AG (2002) Chemical composition of European propolis: expected and unexpected results. Z Naturforsch C 57:530-533.

Bartosz G (2006) Use of spectroscopic probes for detection of reactive oxygen species. Clin Chim Acta 368:53-76.

Benaroudj N, Lee DH, Goldberg AL (2001) Trehalose accumulation during cellular stress protects cells and cellular proteins from damage by oxygen radicals. J Biol Chem 276:2426124267.

Benkovic V, Kopjar N, Horvat Knezevic A, Dikic D, Basic I, Ramic S, Viculin T, Knezevic F, Orolic N (2008) Evaluation of radioprotective effects of propolis and quercetin on human white blood cells in vitro. Biol Pharm Bull 31:1778.

Bonatto D (2007) A systems biology analysis of protein-protein interactions between yeast superoxide dismutases and DNA repair pathways. Free Radical Biol Med 43:557-567.

Bouayed J, Bohn T (2010) Exogenous antioxidants - Doubleedged swords in cellular redox state: Health beneficial effects at physiologic doses $v$ s. deleterious effects at high doses. Oxid Med Cell Longevity 1:228-237.

Boukraâ L, Sulaiman SA (2009) Rediscovering the antibiotics of the hive. Recent Pat Anti-Infect Drug Discovery 4:206-213. 
Castro FAV, Herdeiro RS, Panek AD, Eleutherio ECA, Pereira MD (2007) Menadione stress in Saccharomyces cerevisiae strains deficient in the glutathione transferases. Biochim Biophys Acta 1770:213-220.

Dani C, Bonatto D, Salvador M, Pereira MD, Henriques JAP, Eleutherio ECA (2008) Antioxidant protection of resveratrol and catechin in Saccharomyces cerevisiae. J Agric Food Chem 56:4268-4272.

Dobrowolski JW, Vohora SB, Sharma K, Shah SA, Naqvi SA, Dandiya PC (1991) Antibacterial, antifungal, antiamoebic, antiinflammatory and antipyretic studies on propolis bee products. J Ethnopharmacol 35:77-82.

Fernandes PN, Mannarino SC, Silva CG, Pereira MD, Panek AD, Eleutherio ECA (2007) Oxidative stress response in eukaryotes: effect of glutathione, superoxide dismutase and catalase on adaptation to peroxide and menadione stresses in Saccharomyces cerevisiae. Redox Rep 12:236-244.

Forman HJ, Zhang H, Rinna A (2009) Glutathione: overview of its protective roles, measurement, and biosynthesis. Mol Aspects Med 30:1-12.

Fridovich I (1995) Superoxide radical and superoxide dismutases. Annu Rev Biochem 64:97-112.

Gómez-Caravaca AM, Gómez-Romero M, Arráez-Román D, Segura-Carretero A, Fernández-Gutiérrez A (2006) Advances in the analysis of phenolic compounds in products derived from bees. J Pharm Biomed Anal 41:1220-1234.

Hayes JD, Flanangan JU, Jowsey IR (2005) Glutathione transferases. Annu. Rev Pharmacol Toxicol 45:51-88.

Hwang ES, Kim GH (2007) Biomarkers for oxidative stress status of DNA, lipids, and proteins in vitro and in vivo cancer research. Toxicol 229:1-10.

Kakinuma K, Yamaguchi T, Kaneda M, Shimada K, Tomita Y, Chance B (1979) A determination of $\mathrm{H}_{2} \mathrm{O}_{2}$ release by the treatment of human blood polymorphonuclear leukocytes with myristate. J Biochem 86:87-95.

Kanbur M, Atalay O, Ica A, Eraslan G, Cam Y (2008) The curative and antioxidative efficiency of doramectin and doramectin+vitamin AD3E treatment on Psoroptes cuniculi infestation in rabbits. Res Vet Sci 85:291-293.

Khurana V, Lindquist S (2010) Modelling neurodegeneration in Saccharomyces cerevisiae: why cook with baker's yeast? Nat. Rev Neurosci 11:436-449.

Liedhegner EAS, Gao XH, Mieyal JJ (2012) Mechanisms of altered redox regulation in neurodegenerative diseases - Focus on S-glutathionylation. Antioxid Redox Signal 16:543-66.

Lushchak VI (2011) Adaptive response to oxidative stress: Bacteria, fungi, plants and animals. Comp. Biochem. Physiol C Comp Pharmacol 153:175-190.

Mager WH, Winderickx J (2005) Yeast as a model for medical and medicinal research. Trends Pharmacol Sci 26:265-273.

Mannarino SC, Vilela LF, Brasil AA, Aranha JN, MoradasFerreira P, Pereira MD, Costa V, Eleutherio ECA (2011) Requirement of glutathione for Sod1 activation during lifespan extension. Yeast 28:19-25.

Marcucci MC, Ferreres F, García-Viguera C, Bankova VS, De Castro SL, Dantas AP, Valente PH, Paulino N (2001) Phe- nolic compounds from Brazilian propolis with pharmacological activities. J Ethnopharmacol 74:105-112.

Mauzeroll J, Bard AJ (2004) Scanning electrochemical microscopy of menadione-glutathione conjugate export from yeast cells. Proc Natl Acad Sci U.S.A. 101:7862-7867.

Morano KA, Grant CM, Moye-Rowley WS (2011) The response to heat shock and oxidative stress in Saccharomyces cerevisiae. Genetics http://www.ncbi.nlm.nih.gov/pubmed?term=10.1534\%2Fg enetics.111.128033.

Nery DCM, Silva CG, Mariani D, Fernandes PN, Pereira MD, Panek AD, Eleutherio ECA (2008) The role of trehalose and its transporter in protection against reactive oxygen species. Biochim Biophys Acta 1780:1408-1411.

Pallardó FV, Markovic J, García JL, Viña J (2009) Role of nuclear glutathione as a key regulator of cell proliferation. Mol Asp Med 30:77-85.

Pereira MD, Eleutherio EC, Panek AD (2001) Acquisition of tolerance against oxidative damage in Saccharomyces cerevisiae. BMC Microbiol 1:11.

Prasad NR, Jeyanthimala K, Ramachandran S (2009) Caffeic acid modulates ultraviolet radiation- $\mathrm{B}$ induced oxidative damage in human blood lymphocytes. J Photochem Photobiol B 95:196-203.

Scandalios JG (2005) Oxidative stress: molecular perception and transduction of signals triggering antioxidant gene defenses. Braz J Med Biol Res 38:995-1014.

Sforcina JM, Bankovab V (2011) Propolis: Is there a potential for the development of new drugs? J Ethnopharmacol 133:253260.

Shimizu K, Ashida H, Matsuura Y, Kanazawaa K (2004) Antioxidative bioavailability of artepillin $\mathrm{C}$ in Brazilian propolis. Arch Biochem Biophys 424:181-188.

Souza RM, Souza MC, Patituci ML, Silva JFM (2007) Evaluation of antioxidant and antimicrobial activities and characterization of bioactive components of two Brazilian propolis samples using a pKa-guided fractionation. $\mathrm{Z}$ Naturforsch $\mathrm{C}$ 62:801-807.

Steels EL, Learmonth RP, Watson K (1994) Stress tolerance and membrane lipid unsaturation in Saccharomyces cerevisiae grown aerobically or anaerobically. Microbiol 140:569-576.

Stickland LH (1951) The determination of small quantities of bacteria by means of the biuret reaction. J Gen Microbiol 5:698-703.

Tanja C, Polak T, Gasperlin L, Raspor P, Jamnik P (2011) Antioxidative Activity of Propolis Extract in Yeast Cells. J Agric Food Chem 59:11449-11455.

Valko M, Leibfritz D, Moncola J, Cronin MTD, Mazura M, Telser J (2007) Free radicals and antioxidants in normal physiological functions and human disease. Int J Biochem \& Cell Biol 39:44-84.

Valko M, Rhodes CJ, Moncola J, Izakovic M, Mazura M (2006) Free radicals, metals and antioxidants in oxidative stressinduced cancer. Chem Biol Interact 160:1-40. 
Viuda-Martos M, Ruiz-Navajas Y, Fernández-López J, PérezÁlvarez JA (2008) Functional properties of honey, propolis, and royal jelly. J Food Sci 73:117-124.

Wallace MA, Bailey S, Fukuto JM, Valentine JS, Gralla EB (2005) Induction of phenotypes resembling CuZn-superoxide dismutase deletion in wild-type yeast cells: an in vivo assay for the role of superoxide in the toxicity of redoxcycling compounds. Chem Res Toxicol 18:1279-1286.

Yonar ME, Yonar SM, Çoban MZ, Eroglu MC (2011) Antioxidant Effect of Propolis Against Exposure to Chromium in Cyprinus carpio. Environ. Toxicol. doi: 10.1002/tox.20782.

All the content of the journal, except where otherwise noted, is licensed under a Creative Commons License CC BY-NC. 